\title{
Pelaksanaan Pembiayaan Murabahah Berdasarkan Prinsip-Prinsip Syariah Di Bank Syariah
}

\author{
Suci Hati Handayani \\ Program Studi Magister Kenotariatan \\ Pascasarjana Universitas Islam Bandung \\ e-mail: sucihatihandayani27@gmail.com
}

\begin{abstract}
Abstrak-Dalam pelaksanaan pembiayaan murabahah seringkali terjadi permasalah mengenai penyerahan objek akad, yang mana akad tersebut tidak memenuhi syarat dan dapat dibatalkan. Tujuan dari penulisan ini adalah untuk mengetahui pandangan hukum ekonomi syariah berkaitan dengan pembiayaan murabahah pada bank syariah. Metode Pendekatan yang digunakan dalam penelitian tesis ini adalah pendekatan yuridis normatif. Hasil dari penelitian ini menunjukkan bahwa pelaksanaan prinsip syariah dalam akad pembiayaan murabahah pada Bank Muamalat telah sesuai dengan prinsip syariah sebagaimana dalam Undang-Undang Perbankan Syariah, dimana pembiayaan yang berdasarkan atas prinsip Islam yaitu tidak mengandung unsur riba, maisir, gharar, haram, dan zalim.
\end{abstract}

\section{Kata Kunci: Pembiayaan, Murabahah, Bank Syariah.}

\begin{abstract}
In the implementation of murabahah financing, problems often occur regarding the surrender of contract objects, for which the contract does not meet the requirements and can be canceled. The purpose of this paper is to find out the views of Islamic economic law relating to murabahah financing on Islamic banks. Method The approach used in this thesis research is a normative juridical approach. The results of this study indicate that the implementation of sharia principles in the murabahah financing contract at Bank Muamalat is in accordance with sharia principles as in the Sharia Banking Act, where financing is based on Islamic principles which do not contain elements of usury, maisir, gharar, haram, and unjust.
\end{abstract}

Keywords: Financing, Murabahah, Bank Syariah.

\section{A. PENDAHULUAN}

Tidak dapat disangka lagi

bahwa pembangunan memerlukan dana yang tidak sedikit dan

berkesinambungan. Dalam hal

pengerahan dana masyarakat tidak

dapat dikesampingkan peranan

lembaga perbankan (Neni Sri

Imaniyati, 2000:138). Sistem ekonomi syariah sekarang ini

semakin berkembang bila

dibandingkan dengan sistem

ekonomi konvensional, hal ini

dapat dibuktikan dengan

banyaknya bank konvensional

yang membuka bank dengan

sistem syariah. Selain itu

pertumbuhan ekonomi syariah juga 
Suci Hati Handayani , Pelaksanaan Pembiayaan Murabahah Berdasarkan Prinsip-Prinsip Syari...

dapat dilihat dari banyaknya perbankan syariah dan lembaga syariah di Indonesia. Salah satu faktor pendukungnya adalah permintaan Islamic Product dari penduduk Indonesia yang sebagian besar adalah muslim. Perbankan syariah semakin marak sejak diterbitkannya Undang-Undang Nomor 10 Tahun 1998 tentang Perbankan yang memungkinkan bank menjalankan dual banking system atau bank konvensional yang dapat mendirikan divisi syariah, dengan adanya undangundang tersebut konvensional mulai melirik dan membuka unit usaha syariah.

Perbankan syariah merupakan sebuah sistem perbankan yang menghadirkan bentuk-bentuk aplikatif dari konsep ekonomi syariah yang dirumuskan secara bijaksana, dalam konteks kekinian permasalahan yang sedang dihadapi oleh bangsa Indonesia, dan dengan tetap memperhatikan kondisi sosio-kultural di dalam mana bangsa ini menuliskan perjalanan sejarahnya. Konsep ekonomi syariah di dalamnya terlakumulasi nilai-nilai, prinsipprinsip, teori-teori serta kaidahkaidah ekonomi syariah yang pada muaranya akan diterapkan ke dalam pelbagai bentuk lembaga ekonomi berbasis agama Islam (Atang Abd. Hakim, 2011:40). Mulai dikenalnya sistem syariah dalam perbankan syariah oleh masyarakat Indonesia adalah karena Bank Syariah layaknya bank umum konvensional dapat juga melayani seluruh aktivitas perbankan sebagaimana umumnya, yaitu lembaga perantara keuangan (intermediasi finance) dimana menghimpun dan menyalurkan dana masyarakat (Neni Sri Imaniyati, 2013:61).

Landasan syariah perbankan syariah adalah ketentuan-ketentuan hukum muamalah, khususnya menyangkut hukum akad. Bentukbentuk akad jual beli yang telah dibahas para ulama dalam fiqih muamalah terbilang banyak. Ada tiga jenis jual beli yang telah banyak dikembangkan sebagai sandaran pokok dalam pembiayaan di perbankan syariah, yaitu: 1) bai' 
Suci Hati Handayani , Pelaksanaan Pembiayaan Murabahah Berdasarkan Prinsip-Prinsip Syari...

al-murabahah (jual beli barang pada harga asal dengan tambahan keuntungan atau margin yang disepakati); 2) bai' as-salam (pembelian barang yang diserahkan dikemudian hari di mana pembayaran dilakukan di muka/tunai); 3) bai' al-istishna (istishna' hampir sama dengan salam yaitu dari segi obyek pesanannya yang harus dibuat atau dipesan terlebih dahulu dengan ciri-ciri khusus, hanya saja pembayaran dilakukan secara bertahap sesuai kesepakatan (M. Syafi'i Antonio, 2001:101).

Sejak awal munculnya dalam fiqih, pembiayaan murabahah ini tampaknya telah digunakan murni untuk tujuan dagang. Murabahah merupakan suatu bentuk jual beli dengan komisi, di mana pembeli biasanya tidak dapat memperoleh barang yang ia inginkan kecuali lewat seorang perantara atau ketika pembeli tidak mau susah-susah mendapatkannya sendiri, sehingga ia mencari jasa seorang perantara. Bank syariah umumnya mengadopsi kosnsep murabahah untuk memberikan pembiayaan jangka pendek kepada para nasabah guna pembelian barang meskipun mungkin nasabah tidak memiliki uang untuk membayar.

Akad mudharabah ini selain digunakan dalam perbankan syariah juga digunakan dalam asuransi syariah. Dana yang terkumpul dari nasabah perusahaan asuransi syariah (premi) diinvestasikan berdasarkan syariah dengan sistem bagi hasil (mudharabah). Sedangkan pada asuransi konvensional investasi dana dilakukan ke lembaga keuangan yang menggunakan bunga (Neni Sri Imaniyati, 2011:155).

Dalam prakteknya pada salah satu bank syariah yaitu Bank Muamalat yang menerapkan pembiayaan murabahah yang bersifat mengikat. Bank Muamalat hanya akan melakukan pembelian barang apabila telah dipastikan ada nasabah yang akan membeli kembali barang tersebut secara murabahah. Dalam menjalankan pembiayaan murabahah, Bank Muamalat menjual barang dengan menegaskan harga perolehan 
Suci Hati Handayani , Pelaksanaan Pembiayaan Murabahah Berdasarkan Prinsip-Prinsip Syari...

barang kepada nasabah secara jujur dan nasabah membayar dengan harga lebih sebagai keuntungan (margin) bagi bank selaku penjual sesuai dengan kesepakatan antara pihak Bank Muamalat dan nasabah. Pembayaran kewajiban dilakukan oleh nasabah secara tangguhan atau cicilan.

Namun, dalam melakukan pembiayaan murabahah dengan memberikan pembiayaan berupa sejumlah uang sesuai dengan pembiayaan yang dibutuhkan kepada nasabah, di mana hal ini disebut dengan akad wakalah, yaitu adanya pemberian kuasa atas dana dan nama bank kepada nasabah untuk melakukan pembelian barang sendiri sesuai spesifikasi yang diinginkan kepada pihak supplier setelah memperoleh pembiayaan dari pihak bank. Hal ini hampir sama dengan pemberian kredit pada bank konvensional, maka penerapan murabahah dengan memberi pembiayaan berupa kuasa pada nasabah, kurang sesuai dalam melakukan penerapan pembiayaan murabahah dengan prinsip syariah.

\begin{abstract}
Berkaitan dengan akad pertukaran, sering terdapat persoalan berkaitan dengan penyerahan objek akad. Bahwa penyerahan benda atau objek akad wajib hukumnnya. Akad pertukaran dalam bentuk jual beli dinilai tidak memenuhi syarat (fasid) dan dapat dibatalkan apabila benda yang menjadi objek akad tidak diserahkan. Akad yang tidak dibarengi dengan penyerahan objek akad dinilai sebagai gharar. Berdasarkan uraian diatas, maka penulis merumuskan permasalahan yang akan dibahas dalam penulisan ini yaitu bagaimanakah pelaksanaan pembiayaan murabahah pada bank syariah yang berdasarkan prinsipprinsip Syariah?
\end{abstract}

\section{B. METODE PENELITIAN}

Metode Pendekatan yang digunakan dalam penelitian tesis ini adalah pendekatan yuridis normatif (Ronny Hanitijo Soemitro, 1994:10), yaitu metode penelitian hukum yang dilakukan dengan meneliti bahan pustaka atau data sekunder. Bahan yang 
Suci Hati Handayani , Pelaksanaan Pembiayaan Murabahah Berdasarkan Prinsip-Prinsip Syari...

diteliti di dalam penelitian hukum normative adalah bahan pustaka atau data sekunder (Salim H. S dan Erlies Septiana Nurbaini, 2013:12). Penelitian ini sering juga disebut penelitian hukum doktrinal, yaitu penelitian hukum yang menggunakan data sekunder, dengan mempelajari dan mengkaji asas-asas hukum, khususnya kaidah-kaidah hukum positif yang berasal dari bahan-bahan kepustakaan, peraturan perundangundangan.

Spesifikasi penelitian pada penulisan tesis ini adalah dengan menggunakan metode deskriptif analisis, suatu penelitian yang menggambarkan suatu kenyataan yang kemudian dianalisis dengan mengumpulkan data-data untuk menggambarkan persoalan yang berkaitan dengan pelaksanaan pembiayaan murabahah pada bank syariah yang berdasarkan prinsipprinsip syariah.

\section{HASIL DAN PEMBAHASAN}

\section{Pembiayaan Murabahah}

\begin{tabular}{cr} 
Perbankan & \multicolumn{2}{c}{ konvensional } \\
sebagi pemain lama telah
\end{tabular}

menawarkan berbagai produk unggulan, salah satunya kredit kepemilikan, baik rumah, kendaraan bermotor atau yang lainnya. Produk bank konvensional tersebut mendapat respon yang sangat bagus dari masyarakat. Oleh karena itu, untuk melengkapi produk unggulannya dan juga untuk dapat mengakomodasi keinginan dari para nasabahnya untuk dapat memiliki rumah, kendaraan bermotor atau yang lainnya, bank syariah menawarkan skim bai' al-murabahah. Murabahah berasal dari kata ribh (keuntungan), yaitu prinsip bai' (jual beli) dimana harga jualnya terdiri dari harga pokok barang ditambah nilai keuntungan (ribh) yang disepakati (Mervyn. K Lewis dan Latifa M. Algaoud, 2001:36).

Pada murabahah, penyerahan barang dilakukan pada saat transaksi sementara pembayarannya dilakukan secara tunai, tangguh ataupun dicicil. Pada murabahah, untuk terbentuknya akad pembiayaan multiguna di dalam Islam, haruslah 
memenuhi rukun-rukun dan syaratsyarat murabahah. Menurut mayoritas (jumhur) ahli-ahli hukum Islam, rukun yang membentuk akad murabahah ada lima, yaitu sebagai berikut (Muhammad Syafi'i Antonio, 2001:28):

a. Adanya penjual (ba'i);

b. Adanya pembeli (mushtari);

c. Objek atau barang (mabi') yang diperjual belikan;

d. Harga (thaman) nilai jual barang berdasarkan mata uang;

e. Ijab qabul (sighah) atau formula akad, suatu pernyataan kehendak oleh masing-masing pihak yang disebut ijab dan qabul.

Sementara itu, syarat murabahah adalah sebagai berikut:

a. Penjual memberitahu biaya modal kepada nasabah;

b. Kontrak pertama harus sah sesuai dengan rukun yang ditetapkan;

c. Kontrak harus bebas riba;

d. Penjual harus menjelaskan kepada pembeli bila terjadi cacat atas barang sesudah pembelian; e. Penjual harus menyampaikan semua hal yang berkaitan dengan pembelian, misalnya jika pembelian dilakukan secara utang. Jadi di sini terlihat adanya unsur keterbukaan.

\section{Prinsip-Prinsip}

Dalam

\section{Pembiayaan Murabahah}

Menurut Undang-Undang

Nomor 21 Tahun 2008 tentang Perbankan Syariah, dalam Pasal 1 ayat 12 dijelaskan bahwa prinsip syariah adalah prinsip hukum Islam dalam kegiatan perbankan berdasarkan fatwa yang dikeluarkan oleh lembaga yang memiliki kewenangan dalam penetapan fatwa di bidang syariah. Selanjutnya dalam Pasal 2 disebutkan bahwa kegiatan usaha yang berasaskan prinsip syariah, antara lain adalah kegiatan usaha yang tidak mengandung unsur diantaranya:

a. Riba, yaitu penambahan pendapatan secara tidak sah (batil).

b. Maisir, yaitu transaksi yang digantungkan kepada suatu keadaan yang tidak pasti dan bersifat untung-untungan. 
c. Gharar, yaitu transaksi yang objeknya tidak jelas, tidak dimiliki, tidak diketahui keberadaannya, atau tidak dapat diserahkan pada saat transaksi dilakukan kecuali diatur lain dalam syariah.

d. Haram, yaitu transaksi yang objeknya dilarang dalam syariah.

e. Zalim, yaitu transaksi yang menimbulkan ketidakadilan bagi pihak lainnya (M. Amin Suma, 2008:1487).

Mengenai prinsip-prinsip syariah dalam pembiayaan murabahah diatur Fatwa Dewan Syariah Nasional Nomor:04/DSNMUI/IV/2000 tentang murabahah, memutuskan bahwa:

a. Ketentuan Umum murabahah dalam Bank Syariah:

1) Bank dan nasabah harus melakukan akad murabahah yang bebas riba.

2) Barang yang diperjualbelikan tidak diharamkan oleh syariah Islam.

3) Bank membiayai sebagian atau seluruh harga pembelian barang yang telah disepakati kualifikasinya.

4) Bank yang membeli barang yang diperlukan nasabah atas nama bank sendiri, dan pembelian ini harus sah dan bebas riba.

5) Bank harus menyampaikan semua hal yang berkaitan dengan pembelian, misalnya jika pembelian dilakukan secara utang.

6) Bank kemudian menjual barang tersebut kepada nasabah (pemesan) dengan harga jual senilai harga beli plus keuntungannya. Dalam kaitan ini Bank harus memberitahu secara jujur harga pokok barang kepada nasabah berikut biaya yang diperlukan.

7) Nasabah membayar harga barang yang telah disepakati tersebut pada jangka waktu tertentu yang telah disepakati.

8) Untuk mencegah terjadinya penyalahgunaan atau kerusakan akad tersebut, pihak bank dapat 
mengadakan perjanjian

khusus dengan nasabah.

9) Jika bank hendak mewakilkan kepada nasabah untuk membeli barang dari pihak ketiga, akad jual beli murabahah harus dilakukan setelah barang, secara prinsip, menjadi milik bank.

b. Ketentuan Murabahah kepada Nasabah:

1) Nasabah mengajukan permohonan dan janji pembelian suatu barang atau asset kepada bank.

2) Jika bank menerima permohonan tersebut, ia harus membeli terlebih dahulu aset yang dipesannya secara sah dengan pedagang.

3) Bank kemudian menawarkan aset tersebut kepada nasabah dan nasabah harus menerima (membeli)-nya sesuai dengan janji yang telah disepakatinya, karena secara hukum janji tersebut mengikat, kemudian kedua belah pihak harus membuat kontrak jual beli.
4) Dalam jual beli ini bank dibolehkan meminta nasabah untuk membayar uang muka saat menandatangani kesepakatan awal pemesanan.

5) Jika nasabah kemudian menolak membeli barang tersebut, biaya riil bank harus dibayar dari uang muka tersebut.

6) Jika nilai uang muka kurang dari kerugian yang harus ditanggung oleh bank, bank dapat meminta kembali sisa kerugiannya kepada nasabah.

7) Jika uang muka memakai kontrak "urbun" sebagai alternatif dari uang muka, maka:

a) Jika nasabah memutuskan untuk membeli barang tersebut, ia tinggal membayar sisa harganya.

b) Jika nasabah batal membeli, uang muka menjadi milik bank maksimal sebesar kerugian yang ditanggung oleh bank akibat pembatalan tersebut; dan 
Suci Hati Handayani , Pelaksanaan Pembiayaan Murabahah Berdasarkan Prinsip-Prinsip Syari...

$$
\begin{aligned}
& \text { jika uang muka tidak } \\
& \text { mencukupi, nasabah } \\
& \text { wajib melunasi } \\
& \text { kekurangannya. }
\end{aligned}
$$

c. Jaminan dalam murabahah:

1) Jaminan dalam murabahah dibolehkan, agar nasabah serius dengan pesanannya.

2) Bank dapat meminta nasabah untuk menyediakan jaminan yang dapat dipegang.

d. Utang dalam murabahah:

1) Secara prinsip, penyelesaian utang nasabah dalam transaksi murabahah tidak ada kaitannya dengan transaksi lain yang dilakukan nasabah dengan pihak ketiga atas barang tersebut. Jika nasabah menjual kembali barang tersebut dengan keuntungan atau kerugian, ia tetap berkewajiban untuk menyelesaikan utangnya kepada bank.

2) Jika nasabah menjual barang tersebut sebelum masa angsuran berakhir, ia tidak wajib segera melunasi seluruh angsurannya.
3) Jika penjualan barang tersebut menyebabkan kerugian, nasabah tetap harus menyelesaikan utangnya sesuai kesepakatan awal. Ia tidak boleh memperlambat pembayaran angsuran atau meminta kerugian itu diperhitungkan.

e. Penundaan Pembayaran dalam murabahah:

1) Nasabah yang memiliki kemampuan tidak dibenarkan menunda penyelesaian utangnya.

2) Jika nasabah menunda-nunda pembayaran dengan sengaja, atau jika salah satu pihak tidak menunaikan kewajibannya, maka penyelesaiannya dilakukan melalui Badan Arbitrasi Syariah setelah tidak tercapai kesepakatan melalui musyawarah.

f. Bangkrut dalam murabahah, jika nasabah telah dinyatakan pailit dan gagal menyelesaikan utangnya, bank harus menunda tagihan utang sampai ia menjadi 
Suci Hati Handayani , Pelaksanaan Pembiayaan Murabahah Berdasarkan Prinsip-Prinsip Syari...

sanggup kembali, atau berdasarkan kesepakatan.

Fatwa Dewan Syariah Nasional Nomor:13/DSNMUI/IX/2000 tentang Uang Muka Dalam Murabahah, memutuskan:

a. Dalam akad pembiayaan murabahah, Lembaga Keuangan Syariah (LKS) dibolehkan untuk meminta uang muka apabila kedua belah pihak bersepakat.

b. Besar jumlah uang muka ditentukan berdasarkan kesepakatan.

c. Jika nasabah membatalkan akad murabahah, nasabah harus memberikan ganti rugi kepada LKS dari uang muka tersebut.

d. Jika jumlah uang muka lebih kecil dari kerugian, LKS dapat meminta tambahan kepada nasabah.

e. Jika jumlah uang muka lebih besar dari kerugian, LKS harus mengembalikan kelebihannya kepada nasabah. Jika salah satu pihak tidak menunaikan kewajibannya atau jika terjadi perselisihan di antara kedua belah pihak, maka penyelesaiannya dilakukan melalui Badan Arbitrase setelah tidak tercapai kesepakatan melalui musyawarah.

Fatwa Dewan Syariah Nasional Nomor:16/DSNMUI/IX/2000 tentang Diskon Dalam Murabahah, memutuskan:

a. Harga (tsaman) dalam jual beli adalah suatu jumlah yang disepakati oleh kedua belah pihak, baik sama dengan nilai (qimah) benda yang menjadi obyek jual beli, lebih tinggi maupun lebih rendah.

b. Harga dalam jual beli murabahah adalah harga beli dan biaya yang diperlukan ditambah keuntungan sesuai dengan kesepakatan.

c. Jika dalam jual beli murabahah LKS mendapat diskon dari supplier, harga sebenarnya adalah harga setelah diskon, karena itu, diskon adalah hak nasabah.

d. Jika pemberian diskon terjadi setelah akad, pembagian diskon tersebut dilakukan berdasarkan perjanjian (persetujuan) yang dimuat dalam akad. 
e. Dalam akad, pembagian diskon setelah setelah akad hendaklah diperjanjikan dan ditandatangani. Jika salah satu pihak tidak menunaikan kewajibannya atau jika terjadi perselisihan di antara kedua belah pihak, maka penyelesaiannya dilakukan melalui Badan Arbitrase setelah tidak tercapai kesepakatan melalui musyawarah.

Fatwa Dewan Syari'ah Nasional Nomor:23/DSNMUI/III/2002 tentang Potongan Pelunasan Dalam Murabahah, memutuskan:

a. Jika nasabah dalam transaksi murabahah melakukan pelunasan pembayaran tepat waktu atau lebih cepat dari waktu yang telah disepakati, LKS boleh memberikan potongan dari kewajiban pembayaran tersebut, dengan syarat tidak diperjanjikan dalam akad.

b. Besar potongan sebagaimana dimaksud di atas diserahkan pada kebijakan dan pertimbangan LKS.

\section{Pelaksanaan Pembiayaan} Murabahah Berdasarkan Prinsip Syariah di Bank Syariah

Pelaksanaan pembiayaan murabahah pada bank Muamalat, dimana nasabah yang mengajukan permohonan harus memenuhi syarat sah perjanjian yaitu, unsur syarat subjektif harus berumur 21 tahun atau telah atau pernah menikah, sehat jasmani dan rohani.

Mengenai objek murabahah tersebut juga harus tertentu, jelas dan merupakan milik yang penuh dari pihak bank misalnya saja objek murabahahnya adalah rumah. Dalam pelaksanaannya pembelian objek murabahah tersebut dilakukan oleh nasabah murabahah itu sendiri atau sebagai wakil dari pihak bank dengan akadwakalahatau perwakilan. Setelah akad wakalah dimana pembeli murabahah tersebut bertindak untuk dan atas nama bank untuk melakukan pembelian objek murabahah tersebut, hal ini dimungkinkan dan tidak menyalahi syariah Islam karena dalam Fatwa 
Suci Hati Handayani , Pelaksanaan Pembiayaan Murabahah Berdasarkan Prinsip-Prinsip Syari...

Dewan Syariah Nasional Nomor:04/DSN-MUI/IV/2000

tentang murabahah, sebagai landasan syariah transaksi murabahah adalah sebagai berikut: Pada bagian pertama angka (9) disebutkan bahwa jika bank bendak mewakilkan kepada nasabah untuk membeli barang dari pihak ketiga, akad jual beli murabahah harus dilakukan setelah barang secara prinsip, menjadi milik bank.

Maka pelaksanaan prinsip syariah dalam akad murabahah pada Bank Muamalat telah sesuai dengan Undang-Undang Perbankan Syariah dan fatwa DSN-MUI. Dalam pembiayaan murabahah nasabah diuntungkan dalam hal tidak dikenakannya bunga dalam murabahah ini sehingga nasabah tidak akan rugi apabila ada kenaikan dan penurunan suku bunga pasar. Sementara pada murabahah yang dipergunakan adalah harga jual yang tidak akan berubah selama masa akad. Dengan demikian, nasabah sejak awal sudah mengetahui jumlah cicilan yang akan dibayarkan selama masa akad dan tidak akan mengalami kenaikan ataupun penurunan. Selain harus memenuhi syarat sah perjanjian yang tercantum dalam Pasal 1320 KUH Perdata. Praktik muamalah dalam Islam pada prinsipnya harus sesuai dan tidak bertentangan dengan norma-norma syariah. Para ahli fiqih sepakat bahwa dalam kegiatan bisnis (muamalah) Islam haruslah menghindari unsur yang dilarang oleh syara' yakni, unsur riba, maisir, gharar, haram, dan zalim.

Unsur maisir dan unsur zalim dalam murabahah dapat dihilangkan dengan adanya kepastian proyek dan tingkat kerjasama. Dalam hal ini nasabah tidak diberatkan dengan fluktuasi tingkat suku bunga bank. Unsur gharar dalam hal ini terjadi bila mengubah sesuatu yang pasti menjadi tidak pasti misalnya saja garar dalam harga atau gabn. Hal ini terjadi jika pembiayaan murabahah untuk rumah dalam waktu 1 tahun dengan margin 5\% atau murabahah untuk rumah dalam waktu 2 (dua) tahun dengan 
Suci Hati Handayani , Pelaksanaan Pembiayaan Murabahah Berdasarkan Prinsip-Prinsip Syari...

margin $10 \%$ kemudian disepakati nasabah.

Ketidakpastian terjadi karena harga yang disepakati tidak jelas, apakah $5 \%$ atau $10 \%$. Kecuali bila nasabah menyatakan setuju melakukan transaksi murabahah untuk rumah dengan margin 5\% dibayar dalam waktu 1 tahun, maka barulah tidak terjadi gharar. Unsur gharar dalam penerapan murabahah dapat dihindari dengan adanya kepastian angsuran pembayaran. Dengan demikian, sudah pasti dapat diprediksikan jumlah angsuran perbulan sesuai dengan jangka waktu pembiayaan yang diajukan nasabah, karena dalam hal ini Bank Muamalat tidak mengenal sistem bunga.

Unsur riba dalam murabahah dapat dihilangkan dengan konsep jual beli, karena pada dasarnya Islam menghalalkan jual beli dan mengharamkan riba. Pada unsur teknisnya nasabah tidak merasa dirugikan oleh pihak bank syariah dengan adanya kejelasan mengenai harga objek yang akan dibeli oleh nasabah dan keuntungan yang diambil oleh bank. Begitu pula dengan objek yang diperjualbelikan harus sudah ada pada saat penandatanganan akad dan objek tersebut tidaklah sesuatu yang diharamkan.

\section{PENUTUP}

Secara umum pelaksanaan prinsip syariah dalam akad pembiayaan murabahah pada Bank Muamalat telah sesuai dengan prinsip syariah sebagaimana dalam UndangUndang Perbankan Syariah, dimana pembiayaan yang berdasarkan atas prinsip Islam yaitu tidak mengandung unsur riba, maisir, gharar, haram, dan zalim. Namun masih ada beberapa yang belum sesuai yang lazimnya perlu diperhatikan yakni pada prinsip transparansi dan keterbukaan bertransaksi.

Bank dalam melaksanakan pembiayaan, khususnya pembiayaan murabahah harus memperhatikan asas-asas hukum dalam kontrak dan prinsip-prinsip syariah dapat diterapkan untuk mengatur hak dan kewajiban antara bank dan nasabah secara 
seimbang serta menjamin kepastian dan perlindungan hukum bagi para pihak dalam pelaksanaan pembiayaan murabahah.

\section{E. DAFTAR PUSTAKA}

Atang Abd. Hakim, Fiqih Perbankan Syariah Transformasi Fiqh Muamalah Kedalam Peraturan PerundangUndangan, Refika Aditama, Bandung, 2011.

M. Amin Suma, Himpunan $U U$ Perdata Islam dan Peraturan Pelaksana Lainnya di Indonesia, Grafndo Persada, Jakarta, 2008.

M. Syafi'i Antonio, Bank Syari'ah: Dari Teori Ke Praktek, Gema Insani Press, Jakarta, 2001.

Mervyn. K Lewis dan Latifa M. Algaoud, Perbankan Syariah, Prinsip, Praktik dan Prospek, Serambi, Jakarta, 2001.

Muhammad Syafi'i Antonio, Bank Syariah dari Teori ke Praktik, Gema Insani Press, Jakarta, 2001.

Neni Sri Imaniyati, Membangun Tatanan Perekonomian Masyarakat Madani
Melalui Pembiayaan Pada Bank Syariah, MIMBAR, Jurnal Sosial dan Pembangunan, Vol. 16, No. 2, Tahun 2000. , Asas Dan Jenis Akad Dalam Hukum Ekonomi Syariah: Implementasinya Pada Usaha Bank Syariah, Mimbar, Vol. 27, No. 2, Desember 2011.

Perbankan

Syariah dalam Perspektif Hukum Ekonomi, Mandar Maju, Bandung, 2013.

Ronny Hanitijo Soemitro, Metodologi Penelitian Hukum dan Jurimetri, Cetakan Kelima, Ghalia Indonesia, Jakarta, 1994.

Salim HS dan Erlies Septiana Nurbaini, Penerapan Teori Hukum Pada Penelitian Tesis dan Disertasi, PT. Raja Grafindo Persada, Jakarta, 2013. 